\title{
IDENTIFIKASI JAMU YANG BEREDAR DI KOTA KENDARI MENGGUNAKAN METODE SPEKTROFOTOMETRI UV-VIS
}

\author{
Muhamad Handoyo Sahumena ${ }^{1 *}$, Ruslin², Asriyanti ${ }^{3}$, Endah Nurrohwinta \\ Djuwarno $^{4}$ \\ 1,2,3 Jurusan Farmasi, Fakultas Farmasi, Universitas Halu Oleo, \\ Jl. HEA Mokodompit, Kampus Hijau Bumi Tridharma Anduonohu Kendari 93232, Indonesia \\ 4 Jurusan Farmasi, Fakultas Olahraga dan Kesehatan, Universitas Negeri Gorontalo, \\ Jl. Jenderal Sudirman No. 06 Kota Gorontalo 96128, Indonesia \\ *Penulis Korespondensi. Email: handoyosahumena@gmail.com
}

\begin{abstract}
ABSTRAK
Jamu dikenal sebagai obat tradisional secara turun temurun yang berasal dari tumbuhtumbuhan. Namun, beberapa pelaku industri menambahkan Bahan Kimia Obat (BKO) seperti asam mefenamat kedalam jamu. Penelitian ini bertujuan untuk menentukan validitas metode dalam analisis asam mefenamat secara spektrofotometri UV-Vis pada jamu yang beredar di beberapa pasar Kota Kendari. Teknik pengambilan sampel yang dilakukan pada penelitian ini adalah metode purposive sampling sehingga mendapakan 5 sampel jamu. Penelitian diawali dengan validasi metode untuk menjamin keakuratan metode dalam menentukan kadar asam mefenamat pada sampel. Hasil validasi metode menunjukkan bahwa metode ini baik untuk mendeteksi adanya BKO asam mefenamat pada jamu dengan nilai parameter validasi yaitu nilai korelasi (r) sebesar 0,998; batas deteksi (LOD) 0,48 $\mu \mathrm{g} / \mathrm{mL}$; batas kuantifikasi (LOQ) $1,63 \mu \mathrm{g} / \mathrm{mL}$; presisi intraday dan interday yang dinyatakan dengan nilai \% simpangan baku relatif berturut turut sebesar $0,014 \%$ dan $0,013 \%$; serta akurasi yang dinyatakan dalam \% recovery sebesar 95,41\% (akurasi 80\%), 99,04\% (akurasi 100\%), dan 102,5\% (akurasi 120\%). Hasil analisis terhadap sampel menggunakan metode yang telah tervalidasi menunjukkan bahwa terdapat jamu dengan kandungan BKO asam mefenamat kadar 0,8\%.
\end{abstract}

Kata Kunci:

Jamu, Spektrofotometri UV-Vis, Asam Mefenamat

$\begin{array}{lcc}\text { Diterima: } & \text { Disetujui: } & \text { Online: } \\ 5-07-2020 & 1-08-2020 & 30-08-2020\end{array}$

ABSTRACT

Jamu is a traditional medicine that contains ingredients or ingredients derived from plants of these ingredients that have been hereditary for medicinal use. However, some industry players add Medicinal Chemicals (BKO) such as mefenamic acid into herbal medicine. This study aims to determine the validity of the method in the analysis of mefenamic acid by UV-Vis spectrophotometry on herbs circulating in several markets in Kendari City. The sampling technique used in this study is purposive sampling method so that it gets 5 herbal samples. The study began with method validation to ensure the accuracy of the method in determining the level of mefenamic acid in the sample. The results of the method validation show that this method is good for detecting the presence of mefenamic acid BKO in herbal medicine with a validation parameter value that is the correlation value $(r)$ of 0.998; detection limit (LOD) $0.48 \mu \mathrm{g} / \mathrm{mL}$; limit of quantification (LOQ) $1.63 \mu \mathrm{g} / \mathrm{mL}$; intraday and interday precision expressed with the value of relative standard deviation $\%$ respectively $0.014 \%$ and $0.013 \%$; and the 
accuracy stated in $\%$ recovery is $95.41 \%(80 \%), 99.04 \%(100 \%)$, and $102.5 \%(120 \%)$. The results of the analysis of the sample using a validated method showed that there were herbs with mefenamic acid BKO content of $0.8 \%$.

Copyright $\odot 2020$ Jsscr. All rights reserved

Keywords:

Jamu; Spectrophotometry UV-Vis; Mefenamic Acid

$\begin{array}{ccc}\text { Received: } & \text { Accepted: } & \text { Online: } \\ 2020-07-5 & 2020-08-1 & 2020-08-30\end{array}$

\section{Pendahuluan}

Obat tradisional yang sampai saat ini masih digemari masyarakat adalah jamu. Jamu umummnya mengandung tumbuh-tumbuhan dan diramu berdasrkan resep turun temurun berdasarkan pengalaman [1]. Tingginya minat masyarakat terhadap penggunaan jamu dan semakin ketatnya persaingan industri jamu di Indonesia, dimanfaatkan oleh industri nakal menambahkan Bahan Kimia Obat (BKO) kedalam produk jamu. Pada tahun 2014 ditemukan 51 obat tradisional yang mengandung BKO dimana 42 diantaranya merupakan produk ilegal [2].

Berbagai macam jenis $\mathrm{BKO}$ yang ditemukan di Indonesia, misalnya saja BKO pada jamu kuat yang ditemukan di Kota Malang [3]. Namun, BKO yang paling sering disalahgunakan dalam sediaan jamu adalah pereda nyeri seperti parasetamol, methampiron, ibuprofen, dan asam mefenamat [1]. Asam mefenamat merupakan obat analgetik dan antiinflamasi golongan Non-Steroid (NSAID) yang digunakan untuk pengobatan osteoarthritis, reumatik, dan nyeri [2]. Terdapat berbagai macam metode analisis dalam penentuan BKO dalam sediaan jamu, misalnya secara KLT-Densitometry, Kromatografi Cair Kinerja Tinggi (KCKT), Kromatografi Gas (KG), serta secara Spektrofotometri UV-Vis [ 8].

Pemilihan suatu metode analisis harus memperhatikan berbagai faktor, seperti tujuan analisis, jenis dan jumlah sampel, ketepatan dan ketelitian yang diinginkan untuk analisis serta biaya yang dibutuhkan, [5]. Berdasarkan struktur kimianya Asam Mefenamat memiliki gugus kromofor dan gugus auksokrom. Senyawa obat yang memiliki gugus kromofor dan gugus auksokrom dapat ditentukan kadarnya secara spektrofotometri UV-Vis .

Spektrofotometri UV-Vis merupakan metode analisis yang menggunakan panjang gelombang UV dan Visible sebagai area serapan untuk mendeteksi senyawa. Pada umumnya senyawa yang dapat diidentivikasi menggunakan Spektrofotometri UV-Vis adalah senyawa yang memilki gugus gugus kromofor dan gugus auksokrom . Pengujian dengan Spektrofotometri UV-Vis tergolong dan cepat cepat jika dibandingkan dengan metode lain.

Validasi metode merupakan elemen penting dari kontrol kualitas. Validasi adalah konfirmasi melalui pemeriksaan dan penyediaan bukti objektif bahwa persyaratan tertentu untuk penggunaan yang dimaksudkan tertentu terpenuhi. Parameter validasi metode analisis meliputi akurasi, presisi, spesifisitas, batas deteksi (Limit of Detection) dan batas kuantifikasi (Limit of Quantification) [12]. 
Berdasarkan uraian di atas, peneliti tertarikuntuk melakukan penelitian tentang validasi metode dan analisis asam mefenamat dengan metode spektrofotometri UV-Vis pada jamu yang beredar di pasar Kota Kendari

\section{Metode}

\subsection{Alat dan Bahan}

Alat-alat yang digunakan pada penelitian ini yaitu gelas kimia (Iwaki Pyrex ${ }^{\circledR}$ ), gelas ukur (Iwaki Pyrex ${ }^{\circledR}$ ), pipet ukur (Iwaki Pyrex ${ }^{\circledR}$ ), vortex mixer (Stuart ${ }^{\circledR}$ ), labu ukur $\left(\right.$ Duran $\left.^{\circledR}\right)$, mikro pipet,pipet tetes, batang pengaduk, spatula, timbangan analitik (Precisa $\left.{ }^{\circledR}\right)$, dan filler, spektrofotometer UV-Vis (Jasco V-630 ${ }^{\circledR}$ ),

Bahan-bahan yang digunakan 5 sampel jamu yang diproleh dari took jamu di kota kendari, baku Asam Mefenamat, metanol pro analis (Merck ${ }^{\circledR}$ ), dan aquades.

\section{2..2 Pengambilan Sampel}

Teknik pengambilan sampel yang dilakukan pada penelitian ini adalah metode purposive sampling. Pengambilan sampel diawali dengan melakukan observasi di lima pasar Kota Kendari yaitu pasar Sentral Kota Kendari, pasar Mall Basah, pasar Baruga, pasar Andonohu, dan pasar Lapulu. Pengambilan sampel pada penelitian ini berdasarkan pertimbangan jamu yang paling banyak diminati oleh konsumen dan ketidak lengkapan informasi pada kemasan seperti nama produsen, khasiat,kandungan dan izin edar berupa nomor notifikasi jamu.

\subsection{Pembuatan Kurva Baku Asam Mefenamat}

a. Pembuatan Larutan BakuAsam Mefenamat $1000 \mu \mathrm{g} / \mathrm{mL}$

Baku Asam Mefenamat ditimbang 100 mg, dimasukkan ke dalam labu ukur 100 mL, lalu ditambahkan metanol sampai tanda tera dan dihomogenkan.

b. Pembuatan Larutan Baku Asam Mefenamat $50 \mu \mathrm{g} / \mathrm{mL}$

Diambil 2,5 mL baku Asam Mefenamat $1000 \mu \mathrm{g} / \mathrm{mL}$ kemudian dimasukkan kedala labu ukur dan ditambahkan metanol hingga $50 \mathrm{~mL}$.

\section{c. Penentuan Panjang Gelombang Maksimal Asam Mefenamat}

Diambil 2,5 mL baku Asam Mefenamat $50 \mu \mathrm{g} / \mathrm{mL}$ kemudian dimasukkan kedala labu ukur dan ditambahkan metanol hingga $50 \mathrm{~mL}$. Sehingga didapatkan larutan Asam Mefenamat dengan konsentrasi $5 \mu \mathrm{g} / \mathrm{mL}$. Diukur serapan maksimalnya pada panjang gelombang 200-400 $\mathrm{nm}$ dengan menggunakan pelarut metanol sebagai blanko.

\section{d. Pembuatan Kurva Baku Asam Mefenamat}

Larutan bakuAsam Mefenamat $50 \mu \mathrm{g} / \mathrm{mL}$ dipipet sebanyak 0,5 mL, 1,5 mL, 2,5 mL, 3,5 $\mathrm{mL}$ dan 4,5 mL, masing-masing dimasukkan kedalam labu ukur $25 \mathrm{~mL}$. Masing-masing labu ukur tersebut ditambahkan metanol sampai tanda tera dan dihomogenkan, sehingga didapatkan larutan Asam Mefenamat dengan konsentrasi $1 \mu \mathrm{g} / \mathrm{mL}, 3 \mu \mathrm{g} / \mathrm{mL}$, $5 \mu \mathrm{g} / \mathrm{mL}, 7 \mu \mathrm{g} / \mathrm{mL}$ dan $9 \mu \mathrm{g} / \mathrm{mL}$. Diukur serapannya pada panjang gelombang maksimal dan digunakan pelarut metanol sebagai blanko. 


\subsection{Validasi Metode}

a. Linieritas

Pengujian linieritas berdasarkan nilai koefisien korelasi (r) pada persamaan regresi linier kurva bakuAsam Mefenamat yang dibuat dengan 5 Variasi konsentrasi yaitu $1 \mu \mathrm{g} / \mathrm{mL}$ $3 \mu \mathrm{g} / \mathrm{mL} 5 \mu \mathrm{g} / \mathrm{mL} 7 \mu \mathrm{g} / \mathrm{mLdan} 9 \mu \mathrm{g} / \mathrm{mL}$.

b. Batas Deteksi (LOD) dan Batas Kuantifikasi (LOQ)

Batas deteksi dan batas kuantitasi dikalkulasikan menggunakan uji statistic dengan persamaan regresi linier dari kurva baku. Dengan cara memplotkan kadar dan absorbansi.

c. Presisi

Pada penelitian ini pengujian presisi ini dilakukan dengan pengukuran absorbansi larutan baku Asam Mefenamat dengan konsentrasi $5 \mu \mathrm{g} / \mathrm{mL}$ pada panjang gelombang maksimal dengan pengulangan sebanyak 10 kali. Presisi keterulangan (repeatability) dilakukan dalam satu hari (intraday) dan pada hari yang berbeda (interday).

d. Akurasi

Pengujian akurasi dilakukan dengan menambahkan larutan baku Asam Mefenamat dengan konsentrasi $1 \mu \mathrm{g} / \mathrm{mL}, 5 \mu \mathrm{g} / \mathrm{mL}$ dan $9 \mu \mathrm{g} / \mathrm{mL}$ ke dalam sampel jamu . Sampel yang telah disiapkan kemudian dipindahkan kedalam kuvet dan diukur dengan spektrofotometer UV-Vis. Keakuratan metode ditetapkan sebagai persen perolehan kembali (\% recovery).

\subsection{Analisis Kadar Asam Mefenamat dalam Sampel}

Penentuan jumlah Asam Mefenamat dalam sampel dihitung dengan persamaan:

Berat $(\mu \mathrm{g})=$ kadar sampel $(\mu \mathrm{g} / \mathrm{mL}) \times$ faktor pengenceran $(\mathrm{mL})$

Kemudian dihitung presentase jumlah Asam Mefenamat per kemasannya, dengan persamaan :

$$
\% \text { Asam Mefenamat }=\frac{\text { jumlah Asam Mefenamatper kemasan }}{\text { berat sediaan per kemasan }} \times 100 \%
$$

\section{Hasil dan Pembahasan}

\subsection{Pengambilan Sampel}

Ditetapkan 5 sampel jamu sebagai sampel dengan kode sampel A, sampel B, sampel C, Sampel D, dan Sampel E. Sampel tersebut diperolh dari beberapa pasar di Kota Kendari. Penetapan banyaknya jumlah sampel ini berdasarkan pertimbangan jamu yang paling banyak diminati oleh konsumen dan berdasarkan ketidaklengkapan informasi pada etiket seperti nama produsen, khasiat dan nomor notifikasi jamu. Beberapa sampel tidak mencantumkan nama produsen, kegunaan, berat bersih sampel, dan izin edar berupa nomor notifikasi jamu. Selain ketidaklengkapan informasi pada kemasan (penandaan), terdapat sampel yang tidak mencantumkan nomor izin edar, dan adapula yang hanya mencantumkan nomor izin edar asal jamu diproduksi, bukan izin edar yang berlaku di Indonesia yaitu nomor notifikasi jamu.

\subsection{Penentuan Panjang Gelombang Maksimal Asam Mefenamat}

Dari hasil pengukuran panjang gelombang maksimal asam mefenamat pada rentang panjang gelombang $200-400 \mathrm{~nm}$ diperoleh serapan maksimal pada panjang gelombang $285 \mathrm{~nm}$ dengan nilai serapan sebesar 0,405. Hasil pengukuran panjang gelombang maksimal larutan baku asam mefenamat yang diperoleh sama dengan panjang gelombang literatur yang ada yaitu $285 \mathrm{~nm}$ (Nerdy,2017). 


\subsection{Validasi Metode}

a. Linieritas

Uji linieritas ini dilakukan dengan membuat kurva baku asam mefenamat. Kurva baku merupakan standar dari sampel tertentu yang dapat digunakan sebagai pedoman ataupun acuan untuk sampel tersebut pada pengamatan. Pembuatan kurva baku asam mefenamat berdasarkan nilai serapan pada konsentrasi $1 \mu \mathrm{g} / \mathrm{mL}, 3 \mu \mathrm{g} / \mathrm{mL}, 5 \mu \mathrm{g} / \mathrm{mL}, 7$ $\mu \mathrm{g} / \mathrm{mL}$ dan $9 \mu \mathrm{g} / \mathrm{mL}$ pada panjang $\lambda_{\text {maks }} 285 \mathrm{~nm}$ dan metanol sebagai blanko. Kurva baku larutan baku asam mefenamat dapat dilihat pada Gambar 1.

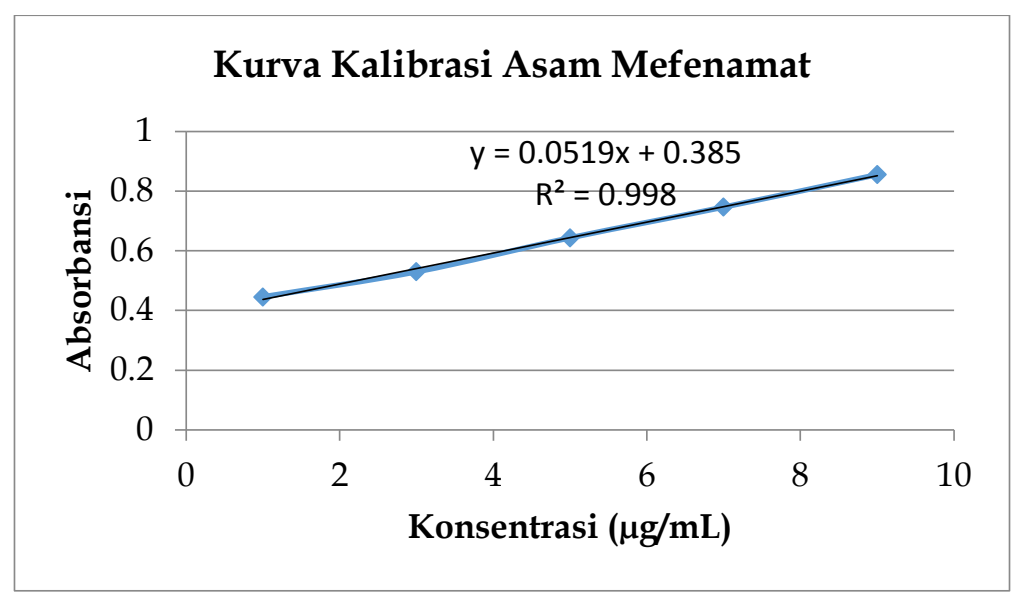

Gambar 2.Kurva baku larutan baku asam mefenamat.

Dari pembuatan kurva baku, didapatkan persamaan regresi linier $y=0,0519 x+0,3854$ dengan koefisien korelasi $(r)=0,998$. Koefisien korelasi yang diperoleh mendekati 1 dan sesuai dengan syarat yang kriteria penerimaan koefisien korelasi yaitu $>0,997$. Sehingga dapat dinyatakan uji linieritas untuk asam mefenamat menghasilkan korelasi yang linier.

\section{b. Batas Deteksi (LOD) dan Batas Kuantitasi (LOQ)}

Dari hasil perhitungan statistik diperoleh nilai $L O D$ sebesar $0,4 \mu \mathrm{g} / \mathrm{mLdan}$ nilai $L O Q$ sebesar 1,6 $\mu \mathrm{g} / \mathrm{mL}$. Nilai $L O D$ menunjukan bahwa pada kosentrasi $0,4 \mu \mathrm{g} / \mathrm{mL}$ merupakan kosentrasi terendah dari larutan baku asam mefenamat yang masih dapat terdeteksi oleh spektrofotometri UV-Vis sedangkan nilai $L O Q$ menunjukan bahwa pada kosentrasi $1,6 \mu \mathrm{g} / \mathrm{mL}$ merupakan kosentrasi tertinggi dari larutan asam mefenamat yang masih dapat dikuantifikasi melalui persamaan regresi yang diperoleh dari kurva baku asam mefenamat.

\section{c. Presisi}

Parameter presisi dinyatakan dengan persentase Relative Standard Deviasion (\% RSD). Hasilnya disajikan pada Tabel 1

Tabel 1. Hasil uji presisi

\begin{tabular}{ccc}
\hline Uji Presisi & \%RSD & \%RSD rata-rata \\
\hline Intra-day & $0,015 \%$ & $0,015 \%$ \\
\hline \multirow{2}{*}{ Inter-day } & $0,015 \%$ & \multirow{2}{*}{$0,014 \%$} \\
\cline { 2 - 3 } & $0,013 \%$ & \\
\hline
\end{tabular}


Hasil perhitungan diperoleh \% RSD untuk presisi intraday adalah 0,014\% dan \% RSD untuk presisi interday dari hari pertama, hari kedua dan hari ketiga secara berturutturut adalah $0,014 \%, 0,013 \%$ dan $0,014 \%$, dengan rerata $\%$ RSD adalah $0,014 \%$. Nilai yang dapat memenuhi kriteria uji presisi yang teliti yaitu sebesar $\leq 2 \%$ (Riyanto, 2014), Hal ini menunjukkan bahwa tingkat ketelitian dari metode yang digunakan sangat baik karena memenuhi kriteria uji

\section{d. Akurasi}

Uji perolehan kembali ini dilakukan dengan penambahan asam mefenamat dengan konsentrasi $1 \mu \mathrm{g} / \mathrm{mL}, 5 \mu \mathrm{g} / \mathrm{mL}$ dan $9 \mu \mathrm{g} / \mathrm{mL}$ dapat dilihat pada Tabel 2

Tabel 2. Hasil uji akurasi asam mefenamat

\begin{tabular}{|c|c|c|c|}
\hline Konsentrasi (x) & Absorbansi (y) & $\%$ recovery & $\begin{array}{l}\text { Rata-rata } \\
\text { \%recovery }\end{array}$ \\
\hline \multirow{3}{*}{1} & 0,433 & 94,11 & \multirow{3}{*}{$95,41 \pm S D$} \\
\hline & 0,433 & 94,11 & \\
\hline & 0,435 & 98,03 & \\
\hline \multirow{3}{*}{5} & 0,638 & 99,21 & \multirow{3}{*}{$99,04 \pm \mathrm{SD}$} \\
\hline & 0,637 & 98,82 & \\
\hline & 0,638 & 99,21 & \\
\hline \multirow{3}{*}{9} & 0,854 & 102,17 & \multirow{3}{*}{$102,5 \pm S D$} \\
\hline & 0,855 & 102,39 & \\
\hline & 0,858 & 103,05 & \\
\hline
\end{tabular}

Berdasarkan hasil perhitungan, rata-rata nilai perolehan kembali dari ketiga konsentrasi $1 \mu \mathrm{g} / \mathrm{mL}, 5 \mu \mathrm{g} / \mathrm{mL}$, dan $9 \mu \mathrm{g} / \mathrm{mL}$ secara berturut-turut adalah 95,41\%,99,04\% dan $102.5 \%$. Hasil rata-rata \% recovery menunjukan bahwa \% recovery sesuai dengan standar yang ditetapkan yaitu $80-110 \%$ [13]

Hasil uji parameter validasi pada penelitian ini dapat dilihat pada tabel 3 :

Tabel 3. Parameter validasi metode analisis

\begin{tabular}{|c|c|c|c|c|}
\hline No & \multicolumn{2}{|c|}{ Parameter Validasi } & Hasil & $\begin{array}{c}\text { Standar yang } \\
\text { Dipersyaratkan }\end{array}$ \\
\hline 1 & \multicolumn{2}{|c|}{ Linearitas } & 0,998 & $>0,997$ \\
\hline 2 & \multicolumn{2}{|c|}{ Batas deteksi (LOD) } & $0,48 \mu \mathrm{g} / \mathrm{Ml}$ & - \\
\hline 3 & \multicolumn{2}{|c|}{ Batas Kuantifikasi (LOQ) } & $1,63 \mu \mathrm{g} / \mathrm{Ml}$ & - \\
\hline \multirow[t]{2}{*}{4} & \multirow{2}{*}{ Presisi } & Intraday & $0,014 \%$ & \multirow{2}{*}{$\leq 2 \%$} \\
\hline & & Interday & $0,013 \%$ & \\
\hline 5 & Akurasi & & $\begin{array}{c}95,41 \%, 99,04 \%, \\
102,5 \%\end{array}$ & $80-110 \%$ \\
\hline
\end{tabular}

Hasil yang diperoleh dari masing-masing parameter validasi sesuai dengan standar yang telah dipersyaratkan yaitu koefisien korelasi untuk parameter linieritas mendekati angka $1(\geq 0,997)$, parameter presisi yang dinyatakan sebagai \%RSD baik presisi intraday maupun presisi intrerday $\leq 2 \%$, \% recovery untuk parameter akurasi berada direntang 80 $110 \%$. Kriteria seksama diberikan jika metode memberikan simpangan baku relatif atau koefisien variasi $\leq 2 \%$ [14]. Hal ini menunjukkan bahwa metode spektrofotometri UVVis yang digunakan untuk menganalisis asam rmefenamat pada jamu memenuhi persyaratan untuk penggunaannya dan dapat dibuktikan kebenarannya. 


\subsection{Analisis Kualitatif dan Kuantitatif}

\section{a. Analisis Kualitatif}

Penelitian ini menggunakan 5 sampel yang diperoleh dari beberapa pasar yang berada di kota Kendari. Berdasarkan bentuk spektra absorbansi menunjukkan bahwa 4 sampel jamu (sampel A, B, D, dan E) dari 5 sampel yang dianalisis menunjukkan spektra yang berbeda dengan spektra larutan baku asam mefenamat. Sedangkan spektra sampel C menunjukkan serapan maksimal panjang gelombang yang sama dengan larutan baku asam mefenamat yaitu pada panjang gelombang $285 \mathrm{~nm}$.

Sampel jamu yang positif mengandung asam mefenamat yaitu sampel C, diukur serapannya pada panjang gelombang maksimal $285 \mathrm{~nm}$. Pengukuran dilakukan secara triplo untuk meminimalkan kesalahan. Serapan yang diperoleh adalah 0,815, 0,816 dan 0,815 , sehingga serapan rata-rata dari sampel $C$ yaitu 0,815 . Perhitungan kadar asma mefenamat didalam sampel sebesar $8,4 \mu \mathrm{g} / \mathrm{mL}$ atau sekitar $0,8 \%$. Hasil analisis menunjukkan bahwa masih terdapat jamu yang mengandung BKO asam mefenamat di Kota Kendari. Hal ini sangat bertentangan dengan Undang-undang No. 36 Tahun 2009 tentang Kesehatan Pasal 196 yang telah ditetapkan oleh pemerintah tentang larangan adanya BKO dalam jamu.

\section{Kesimpulan}

Berdasarkan hasil validasi metode dan analisis asam mefenamat pada beberapa sampel jamu yang beredar di Kota Kendari, dapat disimpulkan bahwa metode spektrofotometri UV-Vis untuk analisis asam mefenamat, diperoleh linieritas 0,998 dari rentang konsentrasi 1-9 $\mu \mathrm{g} / \mathrm{mL}$, batas deteksi $0,48 \mu \mathrm{g} / \mathrm{mL}$ dan batas kuantifikasi 1,63 $\mu \mathrm{g} / \mathrm{mL}$. Metode spektrofotometri UV-Vis menunjukan presisi yang baik dengan \%RSD yang diperoleh baik presisi intraday dan presisi interday adalah $\leq 2 \%$ yaitu $0,014 \%$ untuk presisi intraday dan presisi interday rata rata $\%$ RSD adalah $0,013 \%$, rata-rata $\%$ recovery dari ketiga konsentrasi $1 \mu \mathrm{g} / \mathrm{mL}, 5 \mu \mathrm{g} / \mathrm{mL}$, dan $9 \mu \mathrm{g} / \mathrm{mL}$ secara berturut-turut adalah 95,41\%, 99,4\% dan $102.5 \%$. Kadar BKO jamu yang positif mengandung BKO asam mefenamat di pasar Kota Kendari yaitu 0,8\%.

\section{Referensi}

[1] Yuliarti, Nurheti, 2010, Tips Cerdas Mengkonsumsi Jamu, Penerbit Banyu Medi, Yogyakarta.

[2] Fauziah S.S., Lestari, FLY., dan Hilda A.W. 2015. Pengaruh Pemberian Jamu Pegal Linu Mengandung Bahan Kimia Obat (BKO) terhadap Fungsi Hati Tikus Wistar Jantan. Prosiding Penelitian SpeSIA Unisba. ISSN 2460-6472

[3] Sari, Ayu Kartika. (2012). Analisis Kualitatif Bahan Kimia Obat Dalam Sediaan Jamu Kuat Priadengan Metode Klt-Densitometri Yang Beredar Dikecamatan Klojen Kota Malang. Thesis. Universitas Muhammadiyah Malang.

[4] Sartika, D., Hilda, AW. dan Bertha, R. 2015. Optimasi Metode Ekstraksi Fase Padat dan KCKT untuk Analisis Kuantitatif Bahan Kimia Obat Parasetamol dan Deksametason dalm Jamu Pegal Linu. Prosiding Peneliatian SPeSIA. Unisba.

[5] Hossein, A.Zadeh., Morshedzadeh, F., Rahimpour, E. 2014. Trace analysis of mefenamic acid in human serum and pharmaceutical wastewater samples after 
pre-concentration with $\mathrm{Ni}$-Al layered double hydroxide nano-particles. Journal of Pharmaceutical Analysis. Vol 4, Issue 5, Pages 331-338.

[6] Rahmatullah, S., Slamet, Fikri, A., 2018, Analisis Kualitatif Kandungan Bahan Kimia Obat (BKO) Dalam Jamu Asam Urat Yang Beredar Di Kabupaten Pekalongan, The $7^{\text {th }}$ University Research Colloqium 2018, STIKES PKU Muhammadiyah, Surakarta.

[7] Harmita. 2004. Petunjuk Pelaksanaan Validasi Metode Dan Cara Perhitungannya. Majalah Ilmu Kefarmasian. Vol. I, No.3, 117 - 135.

[8] Rosyada, E., Muliasari, H., Yuanita, E. 2019. Analisis kandungan bahan kimia obat Natrium Diklofenak dalam jamu pegal linu yang dijual di Kota Mataram. Jurnal Ilmiah Farmasi. Vol 15(1), 12-19.

[9] Gandjar, I.G., dan Abdul R., 2007, Kimia Farmasi Analisis, Pustaka Pelajar, Jakarta.

[10] Nerdy,2017,Validation of Ultraviolet Specthrophotometry Method for Determination of Mefenamic Acid Level in Suspension Dosage Forms, Jurnal Natural,Vol. 17 No.3.

[11] Skoog, D.A., Donald M.W., James H.F., dan Stanley R.C., 2014, Fundamentals of Analytical Chemistry, 9th Edition, Brooks/Cole, Cengage Learning, USA.

[12] Riyanto, 2014, Validasi dan Verifikasi Metode Uji, Deepublish, Yogyakarta.

[13] Gandjar, I.G., dan Abdul R., 2012, Analisis Obat Secara Spektrofotometri dan Kromatografi, Pustaka Pelajar, Jakarta.

[14] Harmita. 2004. Petunjuk Pelaksanaan Validasi Metode Dan Cara Perhitungannya. Majalah Ilmu Kefarmasian. Vol. I, No.3, 117 - 135.

[15] Menkes RI, 2012, Peraturan Menteri Kesehatan Republik Indonesia Nomor 007 Tahun 2012 tentang Registrasi Obat Tradisional, Jakarta. 